\title{
"A Dialogue Between Warfighters and Scientists" Designed to Develop Models of Far-Future Military Operations
}

A conference entitled, "Out of the Box and Into the Future: A Dialogue Between Warfighters and Scientists on Far-Future Warfare," the focal point of a larger effort being conducted at the request of U.S. congressional members, will be held on June 26-27, 2000 at the International Trade Center in Washington, DC. The purpose of this conference and associated events is to test current perspectives and generate ideas on how science will change the nature of far-future (Year 2025) military operational areas, through a dialogue among leading science researchers, uniformed military strategists, and the congressional members and staffs who must fund the efforts to prepare for those visions. The conference will bring together forecasting experts in warfighting and science to develop models of far-future military operations across all spectrums in land, sky, sea, and space in order to better understand and prepare for the conflicts of the next century.

The conference opens with a description of the military's Joint Vision 2010, the current warfighting forecast for the future, followed by perspectives from noted scientists and authors of how conflict will change during the new century. High-level military officers will discuss fundamental warfighting parameters that they identify as vitally important, although perhaps contextually different, 25 years from now, including maneuver/power projection, protection, firepower/precision targeting, space and air warfare, information/networking, and intelligence/threat. Speakers will discuss the importance of these parameters, how they may change, and how science and technology (S\&T) can optimize them for military operations in 2025. The second day will consist of S\&T panels describing trends in each field, identifying critical breakthroughs that could herald radical warfighting applications. The S\&T topics include Advanced Materials; Nanotechnologies; Energy; Biomedical; Information and Knowledge; and Human Factors/Neuroscience.

During the weeks following the conference, a Working Group will assimilate the output of the conference, documenting both common and conflicting visions of how science and technology could affect far-future military operations in the year 2025 , and prepare a briefing to be presented by the steering committee, cochairs, and sponsors to members of Congress. After receiving congressional comments, the working group will publish a formal report.

The Conference Co-Chairs are Rep. Curt Weldon (R-PA), Chair, Subcommittee on Military R\&D, House Armed Services Committee; Adm. Harold Gehman, USN, CinC, U.S. Joint Forces Command; and Charles Vest, President, Massachusetts Institute of Technology. Key speakers include William S. Cohen, Secretary of Defense (invited); David Brin, author; Dennis Bushnell, Chief Scientist, NASA Langley; Ralph Merkle, Xerox Palo Alto Research Center; Paul J. McWhorter, Deputy Director, Microsystems Center at Sandia National Laboratories; Irving Wladawsky-Berger, PITAC Co-Chair, IBM Corporation; Stuart Kaufmann, Bios Group LP; and George Whitesides, Harvard University (invited). The conference is sponsored by Potomac Institute for Policy Studies, Office of Naval Research, Air Force Office of Scientific Research, National Intelligence Council, Armed Forces Journal International, U.S. Joint Forces Command, and Coalition for National Security Research.

For more information, access www. potomacinstitute.org/wsconference/ wsconf.htm.

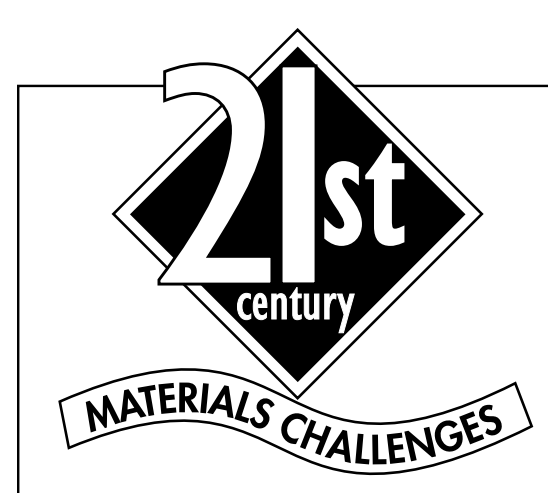

The articles in this series outline the role of materials in society and how their availability and sophistication have shaped societal achievements. 0 ur authors extrapolate and speculate on the materials society would need in the coming century and beyond.

\section{Join MRS Bulletin in its exploration of Materials Challenges in the Next Century!}

A vailable on the $W$ eb

www.mrs.org/ publications/ bulletin/ 21stcen/

N ovember 1999

Posterminaries, Y20K-Looking Back

E.N. Kaufmann,

A rgonne National Laboratory

December 1999

Editorial, Behind the Themes and

Between the Lines

E.L Fleischer, M RS Bulletin Editor

February 2000

A Centennial Report Looking Back on 100 Years of Materials Development A. Cottrell, Cambridge University

January 2000

Introductory Editorial

V.S. A runachalam, Carnegie M ellon University
A pril 2000

Materials for the Human Habitat T.N . G upta, Building Materials and Technology Promotion Council, India

\section{www.mrs.org/ publications/ bulletin/ 21stcen/}

